\title{
Berebut Kendali atas Tanah Baluwarti: Kontestasi Pemerintah Kota Surakarta dan Kasunanan Surakarta atas Tanah Kasultanan dalam Perspektif Game Theory
}

\section{Farida Ari Anggarawati ${ }^{1}$}

\begin{abstract}
Abstrak
Penelitian tentang konflik tanah keraton menggunakan pendekatan administratif, sosial, dan ekonomi. Konflik yang terjadi seakan memosisikan pemerintah memilliki kedudukan yang lebih tinggi daripada keraton. Berbagai kasus menunjukkan kebijakan resmi cenderung sangat jauh berbeda dari realitas sebenarnya, keraton masih menguasai tanah adatnya. Seharusnya, konflik tanah keraton dapat dilihat dari perspektif negara (institusi). Melihat, keraton secara historiografi adalah kerajaan yang berdaulat dengan kebudayaannya yang khas. Artikel ini membahas penguasaan tanah Baluwarti sebagai kontestasi antara negara lama dan negara baru dengan menggunakan game theory antara keraton Kasunanan dan pemerintah kota Surakarta. Relasi kedua negara dijelaskan sebagai aktor rasional yang bertindak sesuai strategi yang telah direncanakan secara maksimal untuk menguasai tanah Baluwarti. Metode penelitian berupa studi lapangan, wawancara interaktif, dari studi kepustakaan, berita media online, dan penelitian terdahulu. Ditemukan ada ketidakjelasan status tanah Baluwarti merupakan strategi yang dipakai kedua aktor untuk mengendalikan tanah Baluwarti. Pemerintah memilih berkonflik dengan keraton Kasunanan di luar tanah Baluwarti dan membuat citra keraton Kasunanan semakin menurun untuk mendapatkan legitimasi dari masyarakat Baluwarti. Sementara itu, Keraton Kasunanan bertahan dengan strateginya untuk tetap menguasai tanah Baluwarti dengan glorifikasi peraturan adatnya dan narasi-narasi jasa keraton Kasunanan kepada Indonesia.
\end{abstract}

Kata Kunci: Penguasaan Tanah; Game Theory; Negara Lama; Negara Baru

1 Penulis adalah mahasiswi Departemen Politik dan Pemerintahan, FISIPOL UGM Email: farida.ari.a@mail.ugm.ac.id 


\section{PENDAHULUAN}

Tanah merupakan salah satu aspek penting bagi setiap individu dalam masyarakat. Tidak hanya dari segi fisiknya, tetapi juga dari segi ekonomi, sosial, dan politik. Hampir semua kegiatan manusia dilakukan di atas tanah. Bagi sebuah kerajaan, tanah merupakan faktor yang sangat berpengaruh untuk melanggengkan kekuasaan raja. Tanah sebagai sumber legitimasi seorang raja, sebagaimana sebuah negara memiliki luas tanah untuk dijadikan daerah negara tersebut berdaulat (Karjoko, 2005).

Pentingnya tanah bagi manusia menyebabkan kontestasi agraria sering terjadi di antarsektor. Indonesia sebagai negara agraris mengatur hukum pertanahan dalam konstitusi Undang-Undang Dasar Negara Republik Indonesia Tahun 1945. Pemerintah mengeluarkan UndangUndang Pokok Agraria No. 5 Tahun 1960 sebagai peraturan pertanahan yang fundamental dan bersifat hukum tanah nasional. Dikeluarkannya UUPA sebagai sebuah pembaruan atas Undang-Undang yang selama ini memuat ketidakadilan sekaligus mengakhiri berbagai persoalan di bidang pertanahan, terutama tanah-tanah eks-keraton atau tanah swapraja. Tetapi yang terjadi sebaliknya, UUPA menyebabkan banyak terjadi konflik tanah, terutama dari masyarakat dan kasultanan atau keraton yang menolak hak tanah kekuasaannya diambil alih oleh negara (Asyhari, 2008). Pada realisasinya, tanah-tanah adat ini masih dikuasai oleh masyarakat atau kerajaan adat yang menguasai daerah tersebut.

Pasca Reformasi, persoalan tanah antara pemerintah dan keraton kembali mengemuka. Di Cirebon, permasalahan tanah terjadi antara pemerintah kota Cirebon dan keraton Kasepuhan Cirebon yang saling klaim hak atas tanah-tanah keraton Kasepuhan Cirebon. Pihak keraton Kasepuhan menolak bahwa tanah keraton Cirebon tergolong tanah swapraja atau bekas swapraja, tetapi mengiyakan sebagai 
tanah wewengkon atau tanah turun-menurun. Permasalahan tersebut diselesaikan dengan cara litigasi yang berakhir dengan pembagian tanah-tanah keraton antara pemerintah kota dan keraton Kasepuhan Cirebon, tetapi pemerintah kota masih menangguhkan status tanah tersebut dan masih berusaha untuk mengambil alih tanah keraton Cirebon.

Di Ternate, terjadi demonstrasi yang dilakukan oleh masyarakat adat Ternate, yaitu menuntut dikembalikannya hak atas tanah Kasultanan kepada Sultan Ternate dan sengketa hak atas tanah Bandara Sultan Babullah yang mencakup empat desa. Pada akhirnya, tanah Kasultanan Ternate dikuasai oleh Kasultanan Ternate walaupun sultansultan Ternate mengakui bahwa tanah Kasultanan Ternate adalah tanah swapraja dan setiap rencana pembangunan dari pemerintah Ternate harus mendapat persetujuan dari sultan Ternate (Asyhari, 2008).

Di Bali, banyak tanah adat yang dijadikan sumber investasi pariwisata seiring berkembangnya fenomena investasi yang selaras dengan kebijakan nasional di bidang penanaman modal. Hal tersebut bertabrakan dengan tanah adat Bali yang tidak dapat dipisahkan dengan ajaran agama (Hindu) dan menjadikan tanah-tanah adat Bali sebagai salah satu tempat yang vital. Pada akhirnya, aktivitas penanaman modal ditentukan oleh keputusan desa adat tersebut, dimana di setiap desa terdapat Majelis Desa Pakraman yang memiliki peran sentral untuk menentukan setiap keputusan pelaksanaan investasi di wilayahnya (Agung, 2017).

Di Surakarta, tanah Baluwarti di keraton Kasunanan Surakarta masih menjadi sengketa atas kepemilikan dan penguasaan antara pemerintah kota, keraton Kasunanan Surakarta, dan penduduk Baluwarti. Tanah Baluwarti berada dalam tembok keraton Kasunanan Surakarta yang sekarang juga menjadi permukiman penduduk yang sebelumnya adalah abdi dalem keraton Surakarta. Status tanah 
Baluwarti secara hukum adalah tanah milik negara berdasarkan UUPA, karena keraton Kasunanan termasuk daerah bekas swapraja sejak dikeluarkannya Peraturan Pemerintah No. 16/SD/1946 dan UU No. 10/1950 tentang Perubahan Daerah Istimewa Surakarta menjadi Keresidenan Surakarta di bawah Provinsi Jawa Tengah.

Setelah dikeluarkannya UUPA, penduduk Baluwarti menuntut untuk mendapatkan SHM, tetapi ditolak keras oleh pihak Kasunanan Surakarta. Keraton mengklaim hak atas tanah Baluwarti masih berada di tangan keraton berdasarkan hak tanah eigendom, dan diperkuat dengan keluarnya Keppres No. 23 Tahun 1988. Tumpang tindih status tanah Baluwarti secara hukum menjadi perdebatan antara keraton Kasunanan dan masyarakat Baluwarti. Pemerintah kota juga terlihat diam dan tidak berusaha mengadvokasikan kebutuhan masyarakat Baluwarti.

Literasi tentang konflik tanah adat yang berkembang cenderung menggunakan pendekatan legal-formal, sosiologi, dan ekonomi. Kompetisi antara hukum negara yang bertabrakan dengan hukum adat adalah konflik horizontal yang memosisikan pemerintah memiliki kedudukan yang lebih tinggi. Sebaliknya, berbagai kasus tentang tanah menunjukkan kebijakan resmi cenderung sangat jauh berbeda dari realitas-realitas sebenarnya, tanah-tanah adat di sebagian besar wilayah Indonesia masih dikuasai oleh kerajaan atau masyarakat adat di daerah tersebut. Hal ini membuktikan kekuasaan dari kerajaan-kerajaan di Indonesia masih memiliki posisi yang dominan dalam penguasaan tanah-tanahnya.

Konflik tanah Baluwarti sangat kompleks, bermula dari penduduk biasa yang bermigrasi dan tinggal di tanah Baluwarti atas ijin keraton Kasunanan selama bertahun-tahun karena lokasi tanah Baluwarti sebagai pusat pemerintahan dan strategis. Pada akhirnya, tanah Baluwarti menjadi permukiman penduduk biasa yang melakukan 
kontrak sewa dengan keraton Kasunanan Surakarta. Setelah berlakunya UUPA, penduduk Baluwarti menuntut diterbitkannya SHM (Sertifikat Hak Milik) kepada pemerintah kota. Hal tersebut mendapatkan penolakan keras dari keraton Kasunanan Surakarta (Tempo.co, 2003).

Permasalahan muncul kembali setelah runtuhnya Orde Baru. Penduduk Baluwarti menolak untuk menyetujui Surat Palilah Griya Pasiten dan mengklaim yang berhak untuk mengelola dan mengatur tanah Baluwarti adalah pemerintah berdasarkan ketentuan Landreform. Keraton Kasunanan Surakarta mengklaim hak atas tanah Baluwarti masih dan tetap berada di tangan keraton. Pemerintah kota Surakarta sebagai kepanjangan tangan dari pemerintah pusat sempat mengeluarkan argumen untuk menerbitkan SHM dan beberapa kali merencanakan pembangunan di tanah Baluwarti juga tidak terealisasikan.

Penguasaan tanah Baluwarti masih berada di tangan keraton Kasunanan sampai sekarang. Setiap rencana yang berhubungan dengan tanah Baluwarti harus mendapatkan persetujuan keraton Kasunanan. Sebaliknya, masyarakat Baluwarti masih mengharapkan bantuan dari pemerintah kota Surakarta untuk menerbitkan status kepemilikan tanah Baluwarti kepada masyarakat Baluwarti dengan hak milik perorangan. Pemerintah kota Surakarta sebagai institusi formal yang memiliki legislasi dalam pengelolaan tanah di Surakarta sampai sekarang belum mengeluarkan tindakan yang tegas tentang status dan pengelolaan tanah Baluwarti. Dalam hal ini, keraton Kasunanan Surakarta harus berhadapan dengan pemerintah kota Surakarta untuk mempertahankan tanah Baluwarti.

Artikel ini menawarkan pembaruan penelitian dengan membahas sengketa tanah Baluwarti sebagai fenomena munculnya kontestasi antara negara lama (keraton Kasunanan) dan negara baru (pemerintah kota Surakarta) dalam penguasaan tanah Baluwarti. Pemerintah kota 
dan keraton Kasunanan Surakarta sebagai dua negara (memiliki kedudukan yang sejajar) yang berupaya merebut kendali atas tanah Baluwarti. Pemerintah memiliki regulasi yang berlaku secara formal, sedangkan Keraton Kasunanan Surakarta dengan kekuatan kontrol atas aset dan adat untuk menguasai tanah Baluwarti.

Perspektif negara dalam artikel ini adalah melihat konflik tanah Baluwarti dengan pendekatan institusi atau lembaga pemerintahan lama bersaing dengan lembaga baru yang diyakini dapat memberikan perubahan pandangan, bagaimana posisi keraton Kasunanan Surakarta tidak hanya sebagai komunitas adat yang sedang redup eksistensinya, tetapi juga sebagai sebuah institusi yang memiliki power atas tanah. Negara dalam hal ini adalah negara lama yang "dijajah" oleh pemerintah sebagai negara baru dengan kekuatan legal formal atas tanah Baluwarti.

Game theory digunakan sebagai dasar teori untuk menjelaskan bagaimana relasi yang terjadi antara negara lama dan negara baru berebut kendali atas tanah Baluwarti. Argumen dalam artikel ini, pertama, tanah Baluwarti adalah arena kontestasi antara keraton Kasunanan dan pemerintah kota Surakarta sebagai fenomena konflik tanah antara negara lama dan negara baru. Kedua, ketidakjelasan status tanah Baluwarti adalah strategi yang dipakai kedua aktor untuk mengendalikan tanah Baluwarti.

Tulisan ini dibagi menjadi tiga bagian utama. Bagian pertama, membahas pentingnya tanah bagi kerajaan sehingga banyak konflik tanah terjadi setelah UUPA dikeluarkan, serta menawarkan pembaruan penelitian dengan melihat kontentasi tanah kerajaan dengan pendekatan institusi dengan menggunakan konsep game theory yang dipercaya dapat menyelidiki situasi kontestasi, interaksi strategis antaraktor, dan strategi optimal yang dipilih oleh antar-aktor. Pendekatan tersebut juga diyakini dapat mengubah cara pandang penelitian sebelumnya, bahwa konflik tanah adat adalah konflik dengan aktor 
yang sejajar dan sama-sama memiliki power yang kuat atas tanah adat. Bagian kedua, membahas awal mula konflik tanah Baluwarti terjadi, menjelaskan kontentasi perebutan kuasa atas tanah Baluwarti antara keraton Kasunanan dengan pemerintah kota Surakarta, dan mengungkap strategi yang dipakai oleh kedua negara dalam rangka menguasai tanah Baluwarti dengan logika game theory. Bagian ketiga adalah kesimpulan yang berisi menekankan kembali argumen dalam artikel ini dan menjawab ketidakjelasan status tanah Baluwarti sampai sekarang, serta memberikan solusi untuk mengakhiri sengketa tanah Baluwarti.

Perspektif negara dalam artikel ini adalah melihat kontentasi dengan pendekatan institusi/lembaga, yaitu melihat keraton Kasunanan adalah institusi adat yang pernah berkuasa secara legal di Surakarta (negara lama) dan pemerintah kota Surakarta sebagai institusi yang legal sekarang ini (negara baru). Negara hanya dapat dipahami dengan baik dalam konteks sejarah. Penelusuran perkembangan sejarah dapat mengidentifikasi beberapa fitur dan proses umum evolusi sebuah negara (Kingston \& Spears, 2004). Pada bukunya, Vincent menyebut Indonesia merdeka pada tanggal 17 Agustus 1945 dengan cara yang tergesa-gesa. Indonesia dikatakan sebagai negara "bayi” yang belum lepas dari bayang-bayang Belanda. Kekalahan Belanda tidak berarti Belanda benar-benar kalah, masih ada kerajaan-kerajaan yang menduduki Indonesia yang berhubungan intens dengan Belanda dan mendapatkan keuntungan dari relasi tersebut.

Jejak sejarah Indonesia terdiri dari beberapa kerajaan besar hampir di seluruh pulau Indonesia. Alih-alih menjadikan Indonesia sebagai negara federal, sebaliknya Indonesia menjadi negara kesatuan. Satu sisi mengharapkan kemerdekaan Indonesia dapat menggabungkan negara lama (kerajaan) dan negara baru (Indonesia), realitanya, banyak konflik terjadi antara pemerintah dan kerajaan (Houben, 2002). 
Sebelum negara Indonesia merdeka, kerajaan-kerajaan besar yang berdaulat memiliki hubungan dengan Belanda berupa Akta Persetujuan (Politik Kontrak), salah satunya adalah keraton Kasunanan Surakarta. Pada masa Kolonial, keraton Kasunanan Surakarta adalah negara pribumi (asli), sebuah entitas yang kompleks berisi lembaga- lembaga dan bentuk-bentuk budaya khas yang tidak sepenuhnya tak bergantung pada pemerintahan Kolonial, mampu memelihara "kegeniusan" masyarakat asli menjadi satu tingkatan lebih tinggi dibanding daerah yang berada di bawah penjajahan langsung Belanda (Houben, 2002). Belanda dan keraton Kasunanan melakukan perjanjian dalam bentuk Akta Persetujuan yang membahas pengelolaan tanah di wilayah kekuasaan, keraton Kasunanan mendapatkan kompensasi dalam bentuk ganti rugi yang menjadikan keraton Kasunanan Surakarta memiliki kekayaan lebih banyak daripada kerajaan-kerajaan di Jawa (Houben, 2002).

Hubungan keraton Kasunanan Surakarta dan Kompeni sebagai sebuah fenomena keraton Kasunanan membentuk sebuah daerah penting yang memiliki historiografi yang luar biasa, dengan konstitusional mereka yang spesifik dan evolusi sosial ekonomi yang khas akan kebudayaannya. Bahkan saat adanya upaya pemberontakan, dari sudut pandang politik, keraton Kasunanan bisa terus mengklaim kedaulatan (parentah) (Houben, 2002).

Pengertian negara yang lebih sempit adalah "country" atau wilayah. Negara membutuhkan wilayahnya untuk kelanjutan negaranya (Bluntschli, 2000). Keberlangsungan keraton Kasunanan Surakarta juga tidak dapat dipisahkan dari tanah kekuasaannya sebagai sumber legitimasi. Tanah Baluwarti adalah wilayah teritorial terakhir yang dimiliki oleh keraton Kasunanan untuk menjalankan negaranya. UUPA dan Landreform menjadikan tanah Baluwarti sebagai arena perebutan antara keraton dan pemerintah kota. Setelah kemerdekaan Indonesia, tanah kekuasaan keraton Kasunanan menjadi masalah, 
yaitu mempertanyakan siapa yang memiliki dan siapa yang menguasai. Ditambah dengan desakan dari masyarakat Baluwarti yang menuntut diterbitkannya SHM kepada pemerintah kota, menjadikan posisi keraton Kasunanan sebagai negara yang semakin terancam dalam menguasai tanah Baluwarti.

Kompleksitas permasalahan tanah Baluwarti memosisikan keraton Kasunanan dan pemerintah kota sebagai dua negara yang merebutkan suatu wilayah untuk menjadi daerah kekuasaannya (Nur Aini Setiawati, 2011). Artikel ini membahas permasalahan tanah Baluwarti antara keraton Kasunanan dan pemerintah kota Surakarta dengan menggunakan game theory. Game theory adalah studi sistematis dari interaksi strategis antar-aktor rasional. Dengan menggunakan teori ini, bagaimana kontestasi yang terjadi antara keraton Kasunanan (negara lama) dan pemerintah kota (negara baru) dalam upaya menguasai tanah Baluwarti dapat dijelaskan dan mengapa status kepemilikan di tanah Baluwarti belum jelas sampai sekarang dapat dijawab. Sekaligus, game theory mampu menjawab bagaimana akhir dari permasalahan tanah Baluwarti. Game theory berasumsi bahwa setiap tindakan yang dilakukan aktor adalah sebuah strategi untuk mendapatkan manfaat yang paling maksimal bagi aktor tersebut. Dalam game theory, kedua negara adalah dua pemain yang memiliki karakter yang rasional dan dalam setiap tindakannya selalu dipengaruhi oleh perubahan insentif. Pada intinya, pemerintah kota maupun keraton Kasunanan akan saling terpengaruh satu sama lain ketika terlibat dalam game theory (Osborne, 2000).

Game theory dikembangkan oleh Jhon Von Neuman dan Morgeistern, berbicara mengenai aktor-aktor rasional yang bertindak sesuai strategi yang telah direncanakan secara maksimal dengan mencari informasi untuk mendapatkan pay off atau manfaat semaksimal mungkin. Dalam game theory terdapat empat elemen dasar, yaitu 
pemain (player), strategi (set of action), informasi (information), dan pay off.

Permasalahan tanah Baluwarti termasuk dalam model extensive game. Model tersebut relevan dengan kasus ini dengan melihat sampai sekarang titik terang kepemilikan tanah Baluwarti belum jelas atau infinity dan keadaan tersebut bisa berubah kapan saja sesuai tindakan pemain. Perubahan strategi tersebut relevan masuk dalam model extensive game dengan informasi sempurna melihat setiap tindakan yang dipilih oleh keraton Kasunanan dan pemerintah saling terbuka dan setiap pemain mengetahui dengan jelas. Extensive game memiliki empat komponen, yaitu pemain (player); terminal sejarah (terminal histories); fungsi pemain (player function); dan preferensi (preference of player).

Pada model ini, pemain mengamati urutan sejarah permainan terlebih dahulu untuk bisa menentukan pemain dalam kejadian tersebut memiliki fungsi seperti apa yang menguntungkan untuk aktor tersebut. Setelah mengamati urutan kejadian (terminal histories), pemain bisa menentukan pilihan strategi. Tidak ada pemain yang meningkatkan insentifnya dengan memilih strategi yang berbeda dari urutan sejarah karena mengingat strategi pemain lain.

Martin J. Osborne mencontohkan extensive game informasi sempurna, dimana ada seorang petahana yang kemungkingan menghadapi persaingan dengan seorang aktor baru yang ingin masuk dalam sebuah bidang dan ingin menjadi pemimpin di bidang tersebut (Osborne, 2000). Petahana memiliki pengalaman yang jauh lebih banyak daripada pemain baru. Dengan melihat sejarah permainan yang pernah dialami oleh petahana, pemain baru memiliki dua pilihan strategi, yaitu masuk atau keluar dalam persaingan pemilihan pimpinan. Jika memilih masuk, pemain baru juga memiliki pilihan strategi lagi, yaitu menyetujui atau bertanding, begitu juga dengan petahana yang sudah 
pasti masuk dalam permainan memiliki pilihan strategi masuk, yaitu menyetujui atau bertanding. Fungsi pemain menetapkan pemain baru untuk menentukan pilihannya terlebih dahulu karena pemain lama sudah pasti masuk dalam permainan. Dengan berbagai informasi yang didapat, pemain baru memiliki pilihan tindakan dan juga mengetahui outcome yang didapat. Setelah itu, pemain baru memiliki preferensi seperti apa yang diinginkan dan akhirnya mendapatkan strategi yang optimal untuk mencapai tujuan dari pemain.

Metode penelitian yang digunakan adalah metode kualitatif dengan teknik pengumpulan data melalui data primer dan sekunder. Data yang dikumpulkan berupa studi lapangan dan wawancara interaktif dengan aktor yang berkepentingan, yaitu pihak dari pemerintah kota Surakarta: Kepala Bagian pemerintahan Sekretaris Daerah Kota Surakarta; Dinas Permukiman, Perumahan, dan Pertanahan Kota Surakarta; Kepala Kelurahan Baluwarti; pihak Keraton Kasunanan Surakarta; dan beberapa masyarakat Baluwarti. Selain itu, data juga berupa pengumpulan data sekunder yang diperoleh dari studi kepustakaan, berita media online dan penelitian terdahulu yang berkaitan dengan masalah pertanahan yang dialami oleh keraton Kasunanan Surakarta. Dokumentasi diambil dalam kurun waktu awal mula permasalahan tanah Baluwarti pada tahun 2002 antara masyarakat Baluwarti, keraton Kasunanan, dan pemerintah kota Surakarta. Data yang didapat menjelaskan bagaimana kontentasi yang terjadi antara pemerintah kota Surakarta sebagai negara baru dan keraton Kasunanan Surakarta sebagai negara lama dalam merebut kendali atas penguasaan tanah Baluwarti di kota Surakarta. 


\section{PEMERINTAH, KASUNANAN, DAN GAME THEORY}

Baluwarti berasal dari kata Portugis, yaitu "balu arte" artinya benteng pertahanan. Daerah Baluwarti berada di sekeliling keraton yang dikelilingi oleh tembok keraton dengan empat pintu besar yang dinamakan "Lawang Gapit”. Daerah Baluwarti memliki luas 40,7 hektar, ditempati oleh raja dan keluarganya (sentana dalem), pegawai kerajaan dan para pejabat (abdi dalem), dan rakyat biasa yang mengabdi pada keraton (kawula dalem). Para abdi dalem yang mengabdi kepada keraton diperbolehkan menempati tanah Baluwarti dengan aturanaturan tertentu, sedangkan yang mengabdi kepada pejabat maupun keluarganya diperbolehkan tinggal dengan sistem magersari. Ada juga abdi dalem yang tinggal satu atap dengan keluarga keraton disebut "ngindhung"(Isbandiyah, 2008).

Pada perkembangannya, banyak pendatang yang masuk dan menjadi warga Baluwarti tanpa memiliki hubungan dengan keraton. Banyaknya pendatang yang menjadi penduduk Baluwarti karena lokasi Baluwarti sangat strategis berada di dalam tembok keraton sebagai pusat pemerintahan. Selain itu, pusat perekonomian juga mengelilingi keraton, yaitu Pasar Gede Harjanagara, Pasar Gading, Pasar Kliwon, dan Pasar Klewer. Letaknya yang strategis berada di pusat pemerintahan dan perekonomian membuat penduduk biasa berlomba-lomba menjadi penduduk Baluwarti dengan menyewa rumah-rumah yang ditinggali oleh para abdi dalem keraton Kasunanan.

Keluarnya Diktum keempat huruf A UUPA (Undang- Undang Pokok Agraria) No. 5 Tahun 1960 yang menyatakan, "Hak-hak dan wewenang atas bumi dan air dari Swapraja atau bekas Swapraja yang masih ada pada waktu mulai berlakunya Undang Undang ini dihapus dan beralih ke negara." Disimpulkan oleh penduduk biasa yang tinggal di tanah Baluwarti bahwa tanah Baluwarti adalah milik negara dan sesuai dengan ketentuan Landreform yang menyatakan sebagian tanah 
yang diambil alih oleh negara juga diberikan kepada masyarakat untuk kesejahteraan masyarakat. Tuntutan tersebut ditolak oleh pihak keraton Kasunanan Surakarta karena berkebalikan dengan Keppres (Keputusan Presiden) No. 23 Tahun 1988 yang menyatakan, “Tanah dan bangunan Keraton Kasunanan Surakarta berikut segala kelengkapan yang terdapat di dalamnya adalah milik Kasunanan Surakarta yang perlu dilestarikan sebagai peninggalan budaya bangsa." Peraturan tersebut diklaim keraton Kasunanan bahwa tanah Baluwarti adalah milik sinuhun. Ditambah dengan penolakan warga Baluwarti melakukan kontrak sewa (Surat Palilah Griya Pasiten) dengan keraton Kasunanan dan menuntut kepada pemerintah kota untuk menerbitkan SHM. Sampai sekarang, status dari tanah Baluwarti belum mencapai kejelasan dan menyebabkan beberapa konflik antara keraton Kasunanan, penduduk Baluwarti, dan pemerintah Kota Surakarta.

Konflik tanah Baluwarti bukan satu-satunya konflik tanah yang pernah dialami oleh keraton Kasunanan. Sebelumnya, ada pemberontakan dari Pangeran Mangkubumi pada tahun 1755 menuntut hak kuasa tanah keraton dan terjadilah "Palihan Negari”, yaitu terbaginya keraton Surakarta Hadiningrat menjadi dua, yaitu keraton Surakarta Hadiningrat dan Kasultanan Ngayogyakarta, maka wilayah keraton Surakarta Hadiningrat pun mengalami penyusutan yang sangat luas (Isbandiyah, 2008). Pemberontakan juga dilakukan oleh RM Said yang menuntut tanah kekuasaannya sendiri dan dikeluarkanlah Perjanjian Salatiga 17 Maret 1757 yang membagi keraton Kasunanan menjadi keraton Kasunanan Surakarta dan Pura Mangkunegaran dengan syarat Mangkunegaran tidak boleh mendirikan alun-alun, tidak boleh memberi hukuman mati dan rutin menghadap sinuhun setiap hari Senin dan Kamis (Santoso, 2002).

Pada masa pemerintahan Hindia Belanda, keraton Kasunanan adalah daerah swapraja. Daerah swapraja adalah daerah pemerintah asli yang kedudukan hukumnya pertama-tama berdasarkan atas hukum itu 
pula, yaitu sebagian statusnya tercantum dalam politik kontrak dengan pemerintah pusat (Kolonial Belanda). Politik kontrak yaitu perjanjian yang menentukan batas-batas hak dan kewajiban antara pemerintah dan swapraja. Perjanjian ini dilakukan antara keraton Kasunanan Surakarta dan pemerintahan Hindia Belanda. Ditetapkannya keraton Kasunanan Surakarta sebagai daerah swapraja menunjukkan keraton Kasunanan memiliki kekuasaan yang kuat dan diakui oleh pemerintah Belanda untuk mengatur pemerintahannya sendiri di kota Surakarta dan sekitarnya (Santoso, 2002). Wilayah Indonesia di Jawa dibagi menjadi dua daerah kekuasaan, yaitu daerah Gubernemen yang dikuasai oleh pemerintah Kolonial Belanda dan daerah Vorstenlanden atau daerah kerajaan di Surakarta dan Yogyakarta. Pola penguasaan tanah di swapraja Surakarta sangat ditentukan oleh raja. Peraturan dasar hukum tanah yang dipakai untuk swapraja Surakarta disusun tersendiri dan berlaku khusus yang dimuat dalam Rijksblad Kasunanan No. 12 s/d No. 15 Tahun 1938 dan Rijksblad Mangkunegaran No. 5 s/d No. 8 Tahun 1938 (Wahyudi, 2005).

Keraton Kasunanan mengalami kemunduran tepat pada saat kemerdekaan Indonesia. Hal ini disebabkan pada masa pemerintahan Belanda, hubungan keraton Kasunanan dengan pemerintah Belanda lebih intens daripada hubungan keraton Kasunanan dengan Kasultanan Yogyakarta. Keraton Kasunanan mendapatkan kompensasi ganti rugi atas pengelolaan tanah kekuasaannya dengan bantuan pemerintah Belanda, dimana hal tersebut tidak terjadi di kasultanan Yogyakarta. Pada saat kemerdekaan Indonesia, keraton Kasunanan Surakarta lebih memilih mempertahankan status quo yang menyebabkan kedaulatannya sebagai negara berakhir (Houben, 2002). Sedangkan Kasultanan Yogyakarta yang langsung menentukan sikap dengan memilih pemerintah Indonesia diberikan status Daerah Istimewa Yogyakarta. 
Keraton Kasunanan sempat ditetapkan sebagai DIS (Daerah Istimewa Surakarta) tetapi tidak berlangsung lama, ada beberapa pemberontakan dari satu golongan yang menolak Daerah Istimewa Surakarta. Surakarta pada saat itu ada ketegangan dari gerakan yang menyebut dirinya gerakan "Revolusi Sosial" yang menuntut hapusnya daerah Istimewa Surakarta, peraturan-peraturan Istimewa tidak sesuai dengan perubahan zaman, dan menuntut digantinya Susuhan (Santoso, 2002). Banyaknya pemberontakan, akhirnya Presiden Soekarno mengeluarkan Penetapan Pemerintah No. 16/SD Tahun 1946 pada tanggal 16 Juli yang menyatakan daerah swapraja Surakarta hapus untuk sementara sebelum membentuk susunan pemerintah daerah Kasunanan ditetapkan dengan Undang-Undang, Kasunanan dan Mangkunegaran merupakan satu Keresidenan.

Belum sempat membentuk struktur pemerintahan, pemerintah Indonesia mengeluarkan Undang-Undang No. 10 Tahun 1950 yang memutuskan dan menghapus pemerintah daerah Keresidenan Semarang, Pati, Pekalongan, Banyumas, Kedu, dan Surakarta; serta membubarkan Dewan Perwakilan Rakyat Daerah KeresidenanKeresidenan tersebut dan menetapkan pembentukan provinsi Jawa Tengah. Dipertegas dengan Undang-Undang No. 16 Tahun 1950 dibentuklah kota Surakarta dan di dalam UU tersebut tidak menentukan tentang kedudukan swapraja Surakarta (Santoso, 2002). Dengan begitu, Surakarta yang sebelumnya adalah daerah istimewa yang dipimpin oleh Keraton dan memiliki kekuasaan sendiri menjadi hapus dan masuk menjadi salah satu kota dalam provinsi Jawa Tengah.

Hilangnya kedudukan keraton Kasunanan atas kepemilikan tanah Baluwarti bermula saat dikeluarkannya UUPA (Undang-Undang Pokok Agraria) No. 5 Tahun 1960 yang menyebutkan, "Hak-hak dan wewenang-wewenang atas bumi dan air dari swapraja atau bekas swapraja yang masih ada pada waktu mulai berlakunya Undang-Undang ini hapus dan beralih kepada negara." Adanya UUPA, kepemilikan 
keraton Kasunanan atas tanahnya hapus dan diambl alih oleh negara. Hal ini dipertegas dengan keluarnya Pasal 4 Peratuan Pemerintah No. 224 Tahun 1961 yang menyatakan, “Tanah swapraja dan bekas swapraja yang dengan ketentuan Diktum IV huruf A Undang-Undang Pokok Agraria beralih kepada negara, diperuntukan sebagian untuk kepentingan pemerintah, sebagian untuk mereka yang langsung dirugikan karena dihapuskannya hak swapraja atas tanah itu, dan sebagian untuk dibagikan kepada rakyat yang membutuhkan.” Keraton Kasunanan yang memiliki kekuasaan penuh di Surakarta semakin dipukul mundur oleh pemerintah dengan adanya peraturan tersebut. Keraton Kasunanan sekarang hanya sebagai sebuah cagar budaya yang harus dijaga dan dilestarikan oleh masyarakat Surakarta seperti kerajaan-kerajaan lainnya di Indonesia, kecuali keraton Kasultanan Yogyakarta.

Keluarnya UUPA menjadi peraturan yang fundamental pada hukum tanah di Indonesia. Namun, pada implementasinya negara belum memberikan kejelasan tentang status-status tanah swapraja yang beralih kepada negara melihat tanah swapraja, khususnya di keraton Kasunanan Surakarta memiliki banyak jenis hak tanah swapraja, meliputi tanah Paringan Dalem, Palilah Anggandhuh turun-menurun, Palilah Anggandhuh, Palilah Magersari, dan Tenggan (Isbandiyah, 2008). Pemberian hak-hak tanah di keraton menurut hukum swapraja dipergunakan untuk abdi dalem dan kerabat keraton sebagai bentuk kepercayaan keraton Kasunanan terhadap para abdi dalem dan kerabat keraton. Begitu juga sebaliknya, abdi dalem dan kerabat keraton akan selalu tunduk kepada raja.

UUPA dan Landreform juga belum mengakomodasikan mengenai subjek hak atas kepemilikan tanah bekas swapraja di keraton Kasunanan, tidak menjelaskan peraturan pelaksanaannya. Dengan demikian, keluarnya UUPA hanya menyebutkan kepemilikan tanah swapraja dan bekas swapraja beralih pada negara, tetapi dalam 
implementasinya keraton Kasunanan masih menguasai tanah tersebut (Isbandiyah, 2008). Hal ini diperkuat dengan keluarnya Keputusan Presiden No. 23 Tahun 1988 tentang Status dan Pengelolaan Keraton Kasunanan Surakarta yang menyatakan tanah dan bangunan keraton Kasunanan adalah milik "sinuhun".

Pada tanggal 31 Januari 1985, keraton Kasunanan mengalami kebakaran besar yang menghanguskan beberapa bangunan inti keraton. Kemudian, Presiden Soeharto membentuk panitia swasta dengan nama Panitia Pembangunan Kembali Keraton Surakarta yang beranggotakan 13 orang dan dipimpin oleh Menko Polkam Surono (Isbandiyah, 2008). Setelah pelaksanaan pemugaran keraton selesai, Presiden Soeharto mengeluarkan Keputusan Presiden No. 23 Tahun 1988 tentang Status dan Pengelolaan Keraton Kasunanan Surakarta yang menegaskan pengembalian aset yang semula dikuasai oleh negara pada keraton Kasunanan Surakarta. Menurut keraton, keluarnya Keppres No. 23 Tahun 1988 menunjukkan bahwa tanah Baluwarti di keraton kembali dimiliki oleh keraton Kasunanan Surakarta.

Keraton Kasunanan Surakarta mulai bangkit dengan mengadvokasikan hak-hak tanah yang seharusnya milik sinuhun. Keraton mulai menyebarkan Surat Palilah Griya Pasiten, yaitu sertifikat yang menyatakan tanah yang dihuni oleh masyarakat Baluwarti adalah milik keraton dan masyarakat yang menduduki tanah tersebut dengan keraton memiliki kontrak sewa yang setelah tiga tahun bisa diperpanjang. Tanah lain yang akan diminta adalah tanah-tanah yang dulu milik sinuhun atau yang disebut Sunan Ground (SG), tanah leluhur, dan tanah pesanggrahan para wali yang menjadi obyek wisata spiritual (Tempo.co, 2003).

Warga yang menggunakan tanah dan bangunan milik keraton, harus secara aktif mendaftarkan kepada keraton, tentang data fisik bangunan dan siapa saja yang menempati bangunan itu. Jauh sebelum 
itu, keraton pernah mengeluarkan peraturan pertanahan pada waktu Paku Buwono X memerintah. Keraton membuat peraturan yang mewajibkan seseorang mengganti uang duduk lumpur. Duduk lumpur adalah usaha dari keraton untuk mengurug tanah di lingkungan keraton yang dulunya berupa rawa-rawa sehingga bisa didirikan bangunan di atasnya. Penarikan uang duduk lumpur ini terus berlangsung sampai terbitnya UUPA (Isbandiyah, 2008). Undang-Undang ini malah membuat kebingungan dan perdebatan tentang siapa yang berhak atas tanah keraton tersebut, sehingga keraton menghentikan penarikan uang duduk lumpur tersebut.

Keraton Kasunanan Surakarta memperkuat legitimasi dengan bergabung dalam Forum Kerajaan Lintas Indonesia bernama Forum Komunikasi Keraton-Keraton se-Indonesia (FKKKI) saat (Festival Keraton Nusantara) FKN I yang diselenggarakan di Solo pada tahun 1995, dibiayai oleh Departemen Pariwisata. FKN II dan pertemuan FKKKI diselenggarakan di Cirebon pada tahun 1997. Mundurnya Soeharto memantik adanya upaya dari para penguasa keraton untuk mendeklarasikan dukungan mereka. Puncaknya pada FKN III yang diselenggarakan di Kutai Kalimantan Timur, September 2002, anggota dari FKKKI bertambah menjadi 34, dimana Sultan Ternate membuat sebuah pernyataan yang mengejutkan dan disetujui oleh para anggota FKKKI bahwa mereka menginginkan tanah mereka kembali yang diambil "pada masa penjajahan dulu" (Davidson, 2007).

Keraton Kasunanan dan keraton-keraton lainnya sibuk untuk menginventaris tanah-tanah yang dianggap milik mereka. Pada FKN IV, para anggota mengedepankan tentang kepemimpinan moral dan mendukung tentang gagasan tentang adanya dewan adat yang berfungsi untuk memberikan wawasan tentang pengetahuan budaya daerah. Anggota FKKKI menjadi aristokratik dengan anggotanya merujuk pada raja dan pemangku adat yang tradisional dan menjadikan sebuah pemerintahan yang jujur, adil, dan pemerintahan yang berakar dalam 
masyarakat setempat menggambarkan kebangkitan negara lama yang telah lama hilang (Davidson, 2007).

Berbagai permasalahan dan ketidakjelasaan pengelolaan tanah di Baluwarti dimanfaatkan oleh keraton untuk memperkuat pertahanan dengan mengklaim hak atas tanah Baluwarti, walaupun upaya keraton Kasunanan untuk bangkit kembali tidak mudah. Warga Baluwarti menolak Surat Palilah Griya Pasiten karena menganggap keraton sudah tidak memiliki hak atas tanah yang sekarang dihuni para warga Baluwarti (Tempo.co, 2003). Warga Baluwarti dalam hal ini memiliki kepentingan sendiri, yaitu ingin menuntut SHM kepada pemerintah berdasarkan yang tertuang dalam UUPA dan dipertegas Pasal 4 PP No. 224 tahun 1961 (Setiyoko, 2013). Selain itu, selama ini warga Baluwarti membayar PBB (Pajak Bumi Bangunan) kepada pemerintah setelah dikeluarkannya UUPA mendorong masyarakat Baluwarti untuk segera mengajukan sertifikat hak milik pribadi atas bangunan yang ditempatinya. Apabila masyarakat Baluwarti menyetujui Surat Palilah, warga Baluwarti akan terus membayar pajak berganda dengan membayar PBB dan kontrak sewa dengan keraton Kasunanan. Ditambah, banyak warga Baluwarti yang meragukan legalitas keraton Kasunanan karena bukan lembaga hukum yang harus mengurusi tanah di Baluwarti. Di sisi lain, pemerintah kota memiliki kepentingan untuk menjaga kepercayaan masyarakat sebagai institusi pemerintah, terkhusus dalam kebutuhan masyarakat atas tanah Baluwarti.

Perkembangan kapitalisme telah mendorong perubahan fungsi tanah dari satu faktor produksi utama menjadi sarana investasi dan mengembangkan kendali di kota Surakarta, salah satunya adalah rencana pemerintah kota Surakarta mengenai pembangunan penggunaan Alun-Alun Lor untuk menampung PKL (Pedagang Kaki Lima), parkir, dan pembangunan kios-kios di tanah Baluwarti yang sampai sekarang selalu menjadi perdebatan antara keraton Kasunanan dan pemerintah kota. 
Permasalahan tanah Baluwarti dari mulai tahun 2003 akhirnya redup dan masih tidak mendapatkan titik terang tentang kejelasan status kepemilikan tanah Baluwarti. Sampai sekarang, penguasaan tanah Baluwarti masih berada di tangan keraton Kasunanan dan mau tidak mau masyarakat Baluwarti membayar sewa yang tercantum dalam Surat Palilah kepada keraton Kasunanan dan membayar PBB kepada pemerintah, masyarakat juga tidak mendapatkan SHM (Sertifikat Hak Milik) atas tanah-tanah yang sudah lama dihuninya lebih dari 30 tahun. Keraton masih berpegang teguh bahwa tanah yang dihuni masyarakat Baluwarti adalah milik keraton. Pada beberapa kasus, tidak jarang beberapa masyarakat Baluwarti mengajukan permohonan SHM kepada BPN (Badan Pertanahan Nasional) dan Dinas Permukiman, Perumahan, dan Pertanahan kota Surakarta namun berakhir gagal karena tidak ada ijin dari pihak keraton Kasunanan Surakarta.

Pemerintah kota Surakarta yang menjadi kepanjangan tangan dari pemerintah pusat dan sebagai instansi pemerintahan yang legal bertanggung jawab untuk menangani permasalahan ini dari awal munculnya konflik antara masyarakat dan keraton Kasunanan juga tidak memberikan tindakan tegas dan memberikan kejelasan status tanah Baluwarti. Kantor kelurahan Baluwarti sebagai instansi pemerintahan yang paling dekat dengan masyarakat Baluwarti dan keraton Kasunanan dari tahun ke tahun juga semakin sedikit mendapatkan laporan adanya konflik tanah di Baluwarti. Masyarakat seakan sudah pasrah dengan keadaan yang sekarang terjadi, mengingat dulu saat konflik tanah Baluwarti sedang marak, pemerintah kota tidak muncul untuk mengadvokasikan kebutuhan masyarakat dan memilih berjalan sendiri dengan mengajukan SHM secara diam-diam walaupun hasil yang didapat nihil.

Hendro Pramono, Kepala Bagian Pemerintahan Sekretaris Daerah kota Surakarta menyatakan tanah Baluwarti sudah jelas adalah milik negara berdasarkan UUPA tahun 1960. Walaupun keraton Kasunanan 
bepegang pada Keppres No. 23 Tahun 1988, tetapi kedudukan UndangUndang dan Keputusan Presiden sudah jelas lebih tinggi UndangUndang. Hak dan kewajiban dari keraton Kasunanan adalah sebagai pengelola bangunan keraton yang berada di tanah Baluwarti sebagai cagar budaya saja, setiap tahun keraton juga mendapatkan dana dari pemerintah untuk pengelolaan keraton sebagai cagar budaya (Suaramerdeka.com, 2018a).

Keraton Kasunanan yang berpedoman pada hukum adat untuk mempertahankan tanah Baluwarti juga bisa disanggah Hendro karena jelas tertuang dalam peraturan yang sudah ada bahwa keraton Kasunanan statusnya sudah diturunkan menjadi cagar budaya yang berada di dalam kota Solo. Hendro Pramono menambahkan, pemerintah kota tidak melakukan tindakan tegas dalam pengaturan tanah Baluwarti karena tidak ada tuntutan dari masyarakat Baluwarti. Apabila masyarakat menuntut SHM dengan pergerakan yang besar dan serentak, maka pemerintah kota melakukan tindakan dalam pengaturan status tanah Baluwarti.

Penanganan pemerintah kota terpecah karena muncul permasalahan baru yang terjadi di internal keraton. Terjadi perebutan tahta raja keraton Kasunanan antara Hangabehi dan Tedjowulan yang mengklaim dirinya sebagai pengganti Raja Paku Buwono XII yang mangkat pada tahun 2004. Permasalahan raja kembar yang bermula pada tahun 2003 sampai sekarang seolah tak berujung (Sunaryo, 2017). Perebutan tahta di dalam keraton yang tak kunjung selesai menyebabkan pemerintah kota sampai turun tangan menjadi mediator antara dua kubu yang berseteru, tetapi tidak membuahkan hasil. Setelah beberapa kali melakukan mediasi, pemerintah akhirnya memberikan peringatan kepada keraton untuk segera menyelesaikan permasalahan kedua raja dengan menghentikan dana hibah dari anggaran APBD kepada keraton Kasunanan sejak tahun 2013. Konflik internal keraton Kasunanan akhirnya terselesaikan pada tahun 2018 dan berlangsung 
damai. Berujung pada, Sinuhun Hangabehi sebagai Raja Keraton Kasunanan dan Tedjowulan sebagai Maha Menteri.

Permasalahan raja kembar keraton juga berimbas pada pemerintah yang dituntut oleh keraton Kasunanan karena tidak memberikan dana hibah sejak tahun 2013. Gugatan tersebut sampai ke tangan Mahkamah Agung, memenangkan keraton Kasunanan dan memutuskan pemerintah wajib memberikan dana hibah kepada keraton Kasunanan. Dengan gugatan tersebut, akhirnya keraton mendapatkan kembali dana hibah dari Provinsi Jawa Tengah sebesar 1,176 Milyar guna menggaji abdi dalem dan untuk pendanaan upacara adat. (Suaramerdeka.com, 2017).

Belum selesai permasalahan raja kembar, pemerintah kota dihadapkan dengan sengketa tanah dengan pihak keraton Kasunanan secara langsung, yaitu perebutan hak milik lahan Taman Sriwedari yang diklaim pihak keraton adalah milik KRMT Wirjodiningrat, kakak ipar Paku Buwono X sebagai warisan yang diberikan Paku Buwono X (Sunaryo, 2015). Sengketa lahan Sriwedari bermula tahun 2015 dan akhirnya selesai di meja hijau pada akhir tahun 2017 dan dimenangkan oleh pemerintah kota karena dari pihak keraton tidak memiliki bukti jelas hak milik tanah Sriwedari ada di tangan KRMT Wirjodiningrat (Reza, 2017).

Kondisi keraton Kasunanan dimanfaatkan pemerintah kota untuk menarik perhatian masyarakat Baluwarti dengan mengeluarkan perencanaan penataaan RTLH (Rumah Tak Layak Huni), dimana tercatat di kelurahan Baluwarti sejak tahun 2015 tercatat sebanyak 337 rumah tergolong tidak layak huni (Wardhani, 2016). Lurah Baluwarti, Suhadi Wahono, mengatakan status penggunaan tanah di Baluwarti rata-rata hanya magersari, yaitu warga memakai atau menyewa tanah milik keraton Solo yang membuat realiasi penanganan RTLH di Baluwarti tidak berjalan lancar karena warga tidak bisa 
menyediakan syarat berupa sertifikat kepemilikan tanah (Okezone. com, 2016). Perencanaan tersebut jelas ditolak oleh pihak keraton dan membuat citra keraton Kasunanan semakin turun di mata masyarakat Baluwarti. Permasalahan RTLH berlangsung selama beberapa bulan, dimana perizinan RTLH dipersulit oleh pihak keraton Kasunanan tanpa alasan yang jelas (Sunaryo, 2016). Pada akhrinya, perencanaan RTLH di Baluwarti gagal karena keidakjelasaan perizinan dari keraton Kasunanan.

Pada institusi yang lebih tinggi dan setelah selesai konflik keraton, hubungan pemerintah pusat dan keraton Kasunanan tampak berangsur harmonis. Beberapa kali pemerintah pusat dan keraton Kasunanan melakukan pertemuan. Namun, bukan untuk membahas kejelasan tentang status tanah Baluwarti melainkan untuk membahas bagaimana pengelolaan keraton Kasunanan. Presiden Jokowi mengagendakan pertemuan dengan kerabat keraton guna membahas keluh kesah para raja keraton, salah satunya membahas sertifikasi secara nasional tanahtanah aset masyarakat adat. Di dalam acara tersebut, GKR Ayu Koes Indriyah memanfaatkannya, yaitu dengan meminta kepada presiden untuk mengembalikan status Surakarta kembali menjadi Daerah Istimewa Surakarta (Suaramerdeka.com, 2018c).

Pemerintah pusat akhirnya juga membentuk UPT Balai Pelestarian Cagar Budaya yang sempat terhenti karena konflik keraton. Pemerintah juga mengajak untuk duduk bersama kerabat keraton dalam rangka membahas pengelolaan keraton. Pemerintah memiliki tujuan untuk melestarikan budaya dan pemerintah sudah memberikan sumber daya salah satunya adalah anggaran. Perwakilan dari pemerintah pusat juga mengusulkan adanya pembahasan rekonsiliasi dan penataaan otoritas di keraton Kasunanan. (Suaramerdeka.com, 2018e).

Selain itu, Presiden Jokowi berjanji akan merekonstruksi tiga hingga lima keraton anggota Forum Silaturahmi Keraton se-Nusantara 
(FSKN) sebagai bentuk perhatian dan tanggung jawab negara untuk memelihara pusat-pusat budaya yang pernah ikut mendirikan NKRI. Setjen Forum Komunikasi dan Informasi Keraton se-Nusantara (FKIKN) yang berkedudukan di kota Solo berharap keraton Surakarta harus menjadi prioritas dalam upaya pelestarian, mengingat jasajasa keraton, apalagi Presiden Jokowi berasal dari Solo. Keraton juga mendorong pemerintah untuk memperhatikan anggota FSKN yang masih eksis. Pemerintah kota juga memberikan bantuan dana dari APBD 2018 untuk keraton Kasunanan dalam acara FSKN sebesar 700 juta (Suaramerdeka.com, 2018d).

Pihak keraton merespons rencana pemerintah dengan mengeluarkan narasi-narasi kewajiban pemerintah untuk membantu keraton tanpa mengajukan proposal bantuan pemerintah. Pengageng Sasana Wilapa, GKR Wandansari Koes Moertijah yang akrab disapa Gusti Moeng menegaskan hal tersebut karena jasa-jasa Sinuhun PB XII, presiden pertama Soekarno bersepakat membantu keraton. Peraturan Presiden No. 29/1964, peraturan yang lahir sebagai wujud kesepakatan antara Presiden Soekarno dengan Sinuhun Paku Buwono XII. Presiden menghargai dan menghormati inisiatif sinuhun untuk menggabungkan keraton Surakarta menjadi bagian NKRI. Penghargaan itu diwujudkan melalui Surat Keputusan Bersama (SKB) Menteri Koordinator Kompartemen Hukum dan Dalam Negeri (kini Kemendagri), Menteri Koordinator Kompartemen Kesejahteraan (kini Kemensos), dan Menteri Koordinator Kompartemen Keuangan (kini Kemenkeu), sebagai pelaksanaan amanat konstitusi (Suaramerdeka. com, 2018b).

Hubungan antara pemerintah pusat dan keraton Kasunanan Surakarta yang semakin harmonis tidak lantas membuat masyarakat Baluwarti bersenang hati. Sampai sekarang, masyarakat Baluwarti masih dihadapkan dengan ketidakjelasan atas status tanah Baluwarti. Pemerintah pusat dan keraton Kasunanan hanya bekerja sama 
dalam hal pengelolaan keraton Kasunanan Surakarta, tidak dalam pembahasan bagaimana pengelolaan tanah Baluwarti dan nasib dari masyarakat Baluwarti. Keraton Kasunanan sibuk dengan narasinya menuntut bantuan dana kepada pemerintah, sedangkan pemerintah pusat sampai sekarang fokus untuk masuk pintu keraton dengan iming-iming pembangunan bangunan keraton, serta bantuan dana untuk keraton Kasunanan Surakarta.

Permasalahan tanah Baluwarti yang terbengkalai dilihat dengan logika game theory merujuk pada pemerintah kota adalah pemain baru dan keraton Kasunanan Surakarta adalah pemain lama. Kedua pemain memiliki pemikiran yang rasional dan dalam setiap tindakannya selalu dipengaruhi oleh perubahan insentif. Keraton Kasunanan Surakarta sebagai pemain lama sudah memiliki banyak pengalaman dalam menghadapi lawan, seperti yang telah diceritakan sebelumnya tentang sejarah penguasaan tanah keraton. Sengketa tanah Baluwarti bukan satu-satunya konflik tanah yang dihadapi keraton Kasunanan, sedangkan pemerintah kota belum memiliki pengalaman memainkan "permainan" penguasaan tanah. Apalagi tanah Baluwarti bukan tanah biasa, dimana pemerintah kota harus berhadapan dengan keraton Kasunanan yang notabene menjadi pendiri Surakarta.

Sejarah konflik tanah keraton yang pernah dialami oleh keraton Kasunanan dengan aktor-aktor sebelumnya menunjukkan bahwa konflik tersebut berhasil diselesaikan karena kedua aktor memilih untuk berkompromi dan membagi tanah kekuasaan. Namun, berbeda dengan tanah Baluwarti kali ini, dimana terminal histories menunjukkan adanya kekecewaan dari keraton Kasunanan terhadap pemerintah pusat yang berimbas pada pemerintah kota. Keluarnya PP No. 16/SD/1946 tentang Pembekuan Keraton Kasunanan sebagai DIS, ditambah dengan UU No. 10 Tahun 1950 tentang Penghapusan Keresidenan Surakarta yang membuat keraton Kasunanan memilih 
untuk "berkonflik" dengan pemerintah dengan mempertahankan penguasaan atas tanah Baluwarti.

Ada sedikit peran dari pemerintah pusat dalam kontestasi ini, dimana pemerintah pusat berusaha untuk masuk dalam tembok keraton Kasunanan dengan memulai hubungan kerja sama untuk mengelola keraton Kasunanan bersama, seperti yang sudah dijelaskan sebelumnya. Pemerintah pusat berusaha untuk mengurangi kekuasaan keraton Kasunanan sebagai sebuah kerajaan yang berkuasa di wilayah keraton Kasunanan, sekaligus menarik perhatian masyarakat Baluwarti tentang pengelolaan keraton. Tetapi, hal tersebut tidak berpengaruh atau belum menunjukkan dampak terhadap status penguasaan tanah Baluwarti sampai sekarang.

Game theory model extensive game dengan informasi yang sempurna memodelkan situasi konflik tanah Baluwarti sebagai berikut.

\begin{tabular}{|l|l|l|}
\hline Game & $:$ & Penguasaan tanah Baluwarti \\
\hline Players & $:$ & Pemerintah dan Keraton Kasunanan Surakarta \\
\hline Terminal Histories & $:$ & (masuk, menyetujui); (masuk, berkonflik); dan keluar \\
\hline Player Function P1 & $:$ & Pemerintah; P2: Keraton Kasunanan \\
\hline Preferences & $:$ & $\begin{array}{l}\text { Preferensi Pemerintah diwakili oleh fungsi pay off, } \\
\text { dimana P1 (masuk, menyetujui) = 2; P1 (masuk, } \\
\text { berkonflik) = 0; dan P1 (keluar) = 1. Sedangkan } \\
\text { preferensi keraton diwakili oleh fungsi pay off P2 } \\
\text { (masuk, menyetujui) = 1; dan P2 (masuk berkonflik) } \\
=0 .\end{array}$ \\
\hline
\end{tabular}


Dari permainan di atas dapat dirumuskan sebagai berikut.

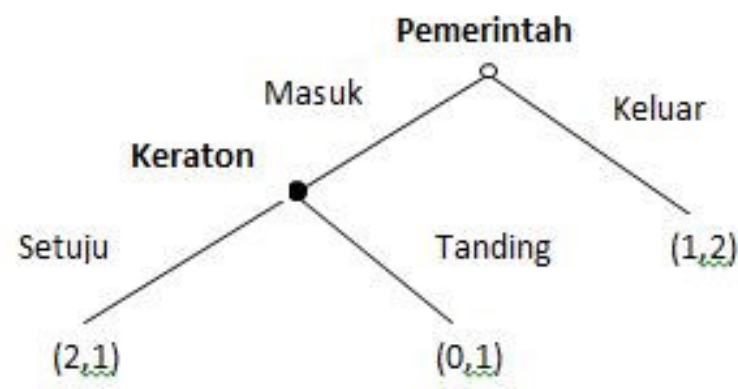

Gambar 1. Penguasaan Tanah Baluwarti Pay Off Pemerintah Kota adalah Angka Pertama dari Setiap Hasil

Perebutan penguasaan tanah Baluwarti antara pemerintah kota dan keraton Kasunanan, dimana pemerintah kota yang mendapatkan giliran pertama untuk menjalankan permainan. Pemerintah Kota memiliki pilihan terminal histories, yaitu masuk atau keluar, sedangkan untuk keraton Kasunanan Surakarta sudah pasti masuk dalam permainan penguasaan tanah Baluwarti melihat perannya sebagai pemain lama. Jika pemerintah kota memilih masuk, ada dua pilihan terminal histories, yaitu memilih menyetujui dan melakukan kompromi dengan keraton Kasunanan, atau memilih berkonflik dengan keraton Kasunanan. Begitu juga dengan keraton Kasunanan memiliki dua pilihan terminal histories menyetujui atau berkonflik dengan pemerintah Kota.

Strategi yang diambil pemerintah kota dalam "permainan" ini memilih keluar dan tidak menanggapi secara tegas permasalahan yang terjadi antara masyarakat Baluwarti dan keraton Kasunanan. Hal ini tampak jelas karena sampai sekarang pemerintah tidak pernah mengambil tindakan tegas dalam pengaturan tanah Baluwarti. Di balik strategi yang dipilih, pemerintah kota memiliki preferensi untuk keluar dengan membuat permasalahan baru dengan keraton Kasunanan, yaitu mengklaim hak atas kepemilikan Sriwedari. Bagi pemerintah kota, 
mengambil hak milik aset keraton Kasunanan satu per satu menjadi strategi yang maksimal, dimana pada akhirnya satu-satunya aset yang dimiliki keraton Kasunanan adalah bangunan Keraton dan tanah Baluwarti yang sekarang berada dalam ketidakjelasan.

Pemerintah kota mengubah atmosfer living culture di keraton Kasunanan menjadi sebuah negara adat yang memiliki stabillitas internal yang buruk. Pemerintah kota unjuk diri sebagai mediator dalam permasalahan "raja kembar" keraton Kasunanan untuk semakin menarik legitimasi masyarakat. Penghentian dana hibah dari APBD juga sebagai ancaman kepada keraton Kasunanan bahwa keraton tidak dapat berjalan sendiri dan sumber daya yang dimiliki tidak bisa untuk menghidupi keraton Kasunanan. Ditambah, perencanaan penataan RTLH dari pemerintah dilakukan untuk menurunkan otoritas keraton Kasunanan. Pemerintah hadir membantu kebutuhan masyarakat Baluwarti, walaupun tahu hal tersebut akan gagal karena tidak mendapatkan izin dari keraton Kasunanan. Strategi pemerintah kota tersebut untuk menciptakan citra yang diharapkan masyarakat Baluwarti, menurunkan wibawa keraton Kasunanan sebagai institusi adat, dan stabilitas internal keraton Kasunanan semakin dipertanyakan. Rasionalitas pemerintah kota dalam sengketa tanah Baluwarti untuk keluar dan memilih berkonflik di luar tanah Baluwarti menjadi strategi yang paling maksimal, dimana pemerintah kota tetap mendapatkan legitimasi dari masyarakat Baluwarti, serta menurunkan citra keraton Kasunanan.

Dari segi materi, biaya yang dikeluarkan pemerintah kota lebih sedikit dibanding berkonflik dengan keraton Kasunanan di tanah Baluwarti. Pemerintah kota "memukul mundur" keraton Kasunanan yang hanya memiliki bangunan keraton sebagai cagar budaya, dimana bangunan tersebut jelas sudah mulai dimasuki oleh pemerintah. Ketidakjelasan tanah Baluwarti tidak terlalu merugikan pemerintah kota selama masyarakat Baluwarti masih mengharapkan bantuan 
pemerintah kota Surakarta. Selain itu, apabila pemerintah kota memilih untuk berkonflik dengan keraton Kasunanan tidak ada jaminan bahwa pemerintah kota akan memenangkan konflik tersebut, melihat terminal histories konflik tanah keraton hanya berhasil diselesaikan lawan keraton Kasunanan dengan memilih masuk dan berkompromi.

Pilihan untuk masuk dan berkompromi dengan keraton Kasunanan juga tidak dipakai oleh pemerintah kota sebagai strategi yang optimal dengan pertimbangan melihat terminal histories keraton Kasunanan sudah menunjukkan sikap anti kepada pemerintah setelah dikeluarkannya peraturan penghapusan kekuasaan keraton Kasunanan secara hukum. Walaupun, pemerintah pusat sudah memulai hubungan yang harmonis dengan keraton Kasunanan Surakarta, tetapi strategi masuk dan berkompromi dengan keraton belum menjamin hasil yang diperoleh pemerintah kota akan semaksimal strategi pemerintah kota keluar dari konflik tanah Baluwarti.

Pilihan untuk masuk dan berkompromi bisa jadi strategi yang optimal untuk keraton Kasunanan, apabila pemerintah kota juga memilih masuk dan berkompromi dengan keraton Kasunanan. Dengan strategi tersebut, keraton Kasunanan akan menguasai tanah Baluwarti secara legal dan mengembalikan citra keraton Kasunanan sebagai kerajaan yang berkuasa.

Rasionalitas keraton Kasunanan sebagai pemain lama dan melihat strategi yang dipilih pemerintah kota, memilih strategi untuk masuk dan berkonflik. Keraton Kasunanan memilih untuk mengklaim tanah Baluwarti adalah milik keraton Kasunanan berdasarkan perjanjian di masa pemerintahan Belanda dan berdasarkan Keppres. Setiap perencanaan pembangunan pemerintah di tanah Baluwarti, keraton Kasunanan selalu melakukan penolakan atas dasar semua perencanaan yang ada di tanah Baluwarti harus seizin keraton Kasunanan sebagai pemilik tanah adatnya. Bangkitnya keraton Kasunanan Surakarta sebagai 
negara lama tidak benar-benar diharapkan masyarakat Baluwarti, tetapi setidaknya keraton Kasunanan masih memiliki kuasa atas tanah Baluwarti dan bangunan keraton Kasunanan. Aset budaya yang dimiliki keraton Kasunanan juga masih menjadi kekuatan tersendiri dari keraton Kasunanan, dimana eksistensi kota Solo bergantung pada keraton Kasunanan yang menjadi cikal bakal berdirinya kota Solo.

Keraton Kasunanan mempertahankan fungsi tanah Baluwarti sebagai pusat pemerintahan dengan nilai adat dan budaya yang luar biasa. Adanya tanah Baluwarti ini dari sebuah kerajaan yang memiliki kekuasaan yang besar dahulunya, seperti pemerintahan sekarang. Keraton Kasunanan tidak ingin menghilangkan esensi dari tanah adatnya, seperti aset dari sebuah kerajaan jauh sebelum Indonesia merdeka, dan melupakan sebuah kerajaan besar yang mempelopori berdirinya negara Indonesia (Suaramerdeka.com, 2018b).

\section{KESIMPULAN}

Dari penjelasan yang dikemukakan, kompleksitas sengketa tanah Baluwarti antara keraton Kasunanan dan pemerintah kota Surakarta adalah arena pertarungan antara negara lama dan negara baru untuk mengembangkan kendali. Game theory membuktikan, dengan modal regulasi yang dimiliki pemerintah kota, dan kekuatan kontrol atas aset dan adat keraton Kasunanan dimanfaatkan kedua kubu untuk mencapai manfaat semaksimal mungkin dalam menguasai tanah Baluwarti. Ketidakjelasan status tanah Baluwarti adalah strategi paling optimal yang dipakai kedua negara untuk mengendalikan tanah Baluwarti.

Pemerintah memilih berkonflik dengan keraton Kasunanan di luar tanah Baluwarti dan membuat citra keraton Kasunanan semakin menurun untuk mendapatkan legitimasi dari masyarakat Baluwarti. Sementara itu, keraton Kasunanan bertahan dengan strateginya untuk tetap menguasai tanah Baluwarti dengan glorifikasi peraturan 
adatnya dan narasi-narasi jasa keraton Kasunanan kepada Indonesia. Sengketa tanah Baluwarti cepat atau lambat harus segera diselesaikan. Strategi paling sempurna dari kacamata game theory untuk mengakhiri kontestasi antara kedua negara, yaitu dengan melakukan rekonsiliasi tentang kepastian status tanah Baluwarti, pembagian wewenang, dan urusan internal. Dengan duduk bersama, keraton Kasunanan dan pemerintah kota Surakarta akan mencapai kesepakatan, menciptakan kesejahteraan masyarakat Baluwarti, tanpa mengancam warisan sejarah yang telah dibangun leluhur. 


\section{REFERENSI}

Agung, I. G. (2017). Eksistensi Tanah Adat di Bali dan Problematika Hukum dalam Pengembangan Investasi. Kertha Pratika, 39 (2), 108-119.

Asyhari, M. (2008). Status Tanah-Tanah Kesultanan Ternate. Mimbar Hukum, 20 (2), 193-410.

Bluntschli, J. K. (2000). The Theory of the State (6th ed.). Kitchener: Batoche Books.

Davidson, J. S. (2007). The Revival of Tradition in Indonesian Politics: the Deployment of Adat from Colonialsm to Indigenism. New York: Routledge.

Houben, V. J. H. (2002). Keraton dan Kompeni: Surakarta dan Yogyakarta, 18301870 (I. Risdiyanto (ed.); 2nd ed.). Bentang Budaya.

Isbandiyah, G. K. (2008). Kebijakan Karaton Surakarta Hadiningrat dalam Pengelolaan Tanah dan Bangunan Setelah Keputusan Presiden Nomor 23 Tahun 1988 Tentang Status dan Pengelolaan Keraton Kasunanan Surakarta di Kelurahan Baluwarti Kota Surakarta. Universitas Diponegoro.

Karjoko, L. (2005). Budaya Hukum Keraton Surakarta dalam Pengaturan Tanah Baluwarti sebagai Kawasan Cagar Budaya. Semarang: Universitas Diponegoro.

Kingston, P., \& Spears, I. S. (2004). States Within States. New York: Palgrave Macmilan.

Nur Aini Setiawati. (2011). Dari Tanah Sultan Menuju Tanah Rakyat: Pola Pemilikan, Penguasaan, dan Sengketa Tanah di Kota Yogyakarta setelah Reorganisasi 1917 (M. N. Salim (ed.); 1st ed.). Yogyakarta: STPN Press.

Okezone.com.(2016). Penanganan Ratusan RTLH Baluwarti Terganjal Status Tanah. Okezone. https://economy.okezone.com/read/2016/03/26/470/1346124/ pena nganan-ratusan-rtlh-baluwarti-terganjal-status-tanah.

Osborne, M. J. (2000). An Introduction to Game theory. Oxford: Oxford University Press. http://pioneer.netserv.chula.ac.th/ptanapo1/gamebook.pdf. 
Reza, M. F. (2017). Berakhirnya Riwayat THR Sriwedari Solo. Tirto. https://tirto. $\mathrm{id} /$ berakhirnya-riwayat-thr-sriwedari-solo-cyli.

Santoso, S. J. (2002). Suara Nurani Keraton Surakarta: Peran Keraton Surakarta dalam Mendukung dan Mempertahankan NKRI. Yogyakarta: Komunitas Studi Didaktika.

Setiyoko, E. (2013, September 3). Warga Magersari Keraton Tuntut Sertifikat SHM. Republika. https://republika.co.id/berita/nasional/jawa-tengah-diynasional/ 13/09/03/msj1gt-warga-magersari-keraton-tuntut-sertifikatshm.

Suaramerdeka.com. (2017). Keraton Akhirnya Akan Terima Dana Hibah. Suara Merdeka.

Suaramerdeka.com. (2018a). Belum Dicabut, Perpres Soal Bantuan Keraton. Suara Merdeka. https://www.suaramerdeka.com/smcetak/baca/60151/ belumdicabut-perpres-soal-bantuan-keraton.

Suaramerdeka.com. (2018b). Pemerintah Wajib Pelihara Keraton Surakarta. Suara Merdeka. https://www.suaramerdeka.com/smcetak/baca/65709/ pemerintah-wajib-pelihara-keraton-surakarta.

Suaramerdeka.com. (2018c). Presiden Agendakan Bertemu Kerabat Keraton. Suara Merdeka. https://www.suaramerdeka.com/smcetak/baca/60467/ presiden-agen dakan-bertemu-kerabat-keraton.

Suaramerdeka.com. (2018d). Presiden Akan Rekonstruksi Lima Keraton Nusantara. Suara Merdeka. https:/www.suaramerdeka.com/smcetak/ baca/108307/presiden-akan-rekonstruksi-lima-keraton-nusantara.

Suaramerdeka.com. (2018e, April 13). Bentuk UPT, Kerabat Keraton Solo Didorong Rekonsiliasi. Suara Merdeka. https://www.suaramerdeka. com/news/baca/30945/ bentuk-upt-kerabat-keraton-solo-didorongrekonsiliasi. 
Sunaryo, A. (2015, September 20). Silang Sengketa Sriwedari, Berebut Warisan Paku Buwono X. Merdeka. https://www.merdeka.com/peristiwa/silangsengketa-sriwedari-berebut-warisan-paku-buwono-x.html.

Sunaryo, A. (2016, April 11). Peliknya Penanganan Rumah Tak Layak Huni di Keraton Surakarta. Merdeka. https://www.merdeka.com/peristiwa/ peliknya-penanganan-rumah-tak-layak-huni-di-keraton-surakarta.html.

Sunaryo, A. (2017, April 7). 13 Tahun Kisruh Keraton Solo Seolah Tak Berujung. Merdeka. https://www.merdeka.com/peristiwa/13-tahun-kisruh-keratonsolo-seolah-tak-berujung.html.

Tempo.co. (2003). Keraton Surakarta Minta Keputusan Presiden Soal Status Tanah. Tempo. https://nasional.tempo.co/read/13043/keraton-surakartaminta-keputu san-presiden-soal-status-tanah.

Wahyudi, B. (2005). Terhadap Tanah-Tanah Bekas Swapraja Implementasi UndangUndang Nomor 5 Tahun 1960 Terhadap Tanah-Tanah Bekas Swapraja. Surakarta: Universitas Muhammadiyah Surakarta.

Wardhani, I. S. (2016). Rumah Tak Layak Huni Solo: Pemkot Minta Palilah Keraton. Solopos. https://soloraya.solopos.com/read/20160323/489/703800/rumahtak-layak-huni-solo-pemkot-minta-palilah-keraton. 